\title{
The effects of cold exposure of pregnant sheep on foetal plasma nutrients, hormones and birth weight
}

\author{
BY G. E. THOMPSON \\ ARC Institute of Animal Physiology, Babraham, Cambridge CB2 4AT \\ AND J. M. BASSETT \\ Nuffield Institute for Medical Research, Oxford OX3 9DS \\ AND DEBBIE E.SAMSON* AND J.SLEE \\ Animal Breeding Research Organization, Edinburgh EH9 $3 J Q$
}

(Received 13 October 1981-Accepted 13 January 1982)

\begin{abstract}
1. Five pregnant sheep, with indwelling catheters positioned for withdrawal of maternal right-atrial and foetal arterial blood, were exposed for $2 \mathrm{~h}$ to neutral and to cold $\left(-1^{\circ}\right.$ and wool-clipped) environmental temperatures. Acute maternal cold exposure increased the concentrations of glucose, glycerol and non-esterified fatty acids in maternal plasma and increased the concentration of glucose in foetal plasma, but not glycerol or non-esterified fatty acids. The concentration of corticosteroids in maternal plasma increased. The concentration of corticosteroids in foetal plasma did not change but the concentration of insulin increased.

2. Thirteen pregnant sheep were housed at thermoneutrality and thirteen similar sheep, fed the same amount of food, were clipped and exposed to cold during the last 5-6 weeks of pregnancy. Chronic maternal cold exposure increased the birth weight of both single and twin lambs.

3. It is concluded that exposure of pregnant sheep to cold can alter the partition of some nutrients between mother and foetus in favour of the foetus, and it is suggested how this may be brought about.
\end{abstract}

Pregnancy, in sheep, commonly occurs during winter but little is known about any effects that maternal exposure to cold may have on foetal nutrition. Pregnant ewes have been clipped while in winter housing, and therefore presumably cold-exposed, and they delivered lambs which were heavier than those from control ewes (Rutter et al. 1971, 1972; Austin \& Young, 1977). However, in most of these experiments food intake was either not measured precisely or not controlled, and would tend to be higher in clipped ewes (Wodzicka-Tomaszewska, 1963; Webster \& Lynch, 1966; Ternouth \& Beattie, 1970) thus confounding any effect of cold exposure on birth weight.

As ambient temperature falls, sheep lose more energy to their environment (Armstrong et al. 1960) therefore, if energy intake of the pregnant ewe is fixed during cold exposure, less energy will remain available to the foeto-maternal unit and foetal growth might be retarded or reduced as it is when the energy intake of the pregnant ewe is reduced (Robinson, 1977). On the other hand, cold exposure might also alter the partition of nutrients between mother and foetus. When sheep are exposed to a cold environmental temperature this increases the concentrations of glucose, non-esterified fatty acids (Halliday et al. 1969) and glycerol (Aulie et al. 1971) in their blood plasma. Some, or all, of the increase of glucose is due to an increased output from the liver into the circulation (Thompson et al. 1978) and the non-esterified fatty acids and glycerol are probably mobilized from adipose tissue. These mobilized substrates are taken up, and used as fuel, by shivering muscle (Bell et al. 1975; Bell \& Thompson, 1979) but in the pregnant animal some may cross the placenta and become available to the foetus.

\footnotetext{
* Present address: Institute of Naval Medicine, Alverstoke PO12 2DL.
} 
The present experiments were undertaken to find out if acute cold exposure of pregnant sheep has any effect on the concentrations of the mobilized nutrients, and of some hormones, in the plasma of their foetuses, and to determine if chronic cold exposure of the mother, whose food intake is controlled, can affect birth weight of the lambs.

\section{MATERIALS AND METHODS}

Animals. Five Clun Forest and twenty-six Scottish Blackface pregnant ewes were used.

Acute cold exposure. The five Clun Forest ewes were housed in individual pens and given $1000 \mathrm{~g}$ chopped hay and 200-250 g concentrated food daily, given at $15-00$ hours. This ration was all eaten. Foetal arterial cannulas were implanted using a modification of the method described by Comline \& Silver (1972). At 102 days of gestation in one ewe, and between 119 and 122 days in four ewes, anaesthesia was induced with Brietal (Eli Lilly and Co. Ltd, Basingstoke) and maintained with Fluothane (ICI Ltd, Macclesfield). The uterus was exposed through a midventral incision and the foetal hindquarters brought through an incision in the anterior border of a uterine horn. The skin inside a foetal leg was incised and a polyvinyl cannula (Dural Plastics Ltd, Dural, Australia) tied into a femoral artery occluding it below the origin of the saphenous artery. The free end of the catheter was brought out through a stab wound in the abdominal wall of the mother. The foetus was injected with $150 \mathrm{mg}$ Orbenin (Beechams Laboratories, Brentford) in saline intra-muscularly, the amniotic fluid with $50 \mathrm{mg}$ Terramycin (Pfizer Ltd, Sandwich) and all wounds sutured. In the first $3 \mathrm{~d}$ after surgery, a saline solution $(9 \mathrm{~g}$ sodium chloride/l) containing $60 \mathrm{mg}$ Crystapen (Glaxo Laboratories, Greenford) and $160 \mathrm{mg}$ Neobiotic (Upjohn Ltd, Crawley) was injected through the foetal cannula. The foetal cannula remained filled with saline containing Terramycin $(1 \mathrm{mg} / \mathrm{ml})$ and heparin $(500 \mathrm{i} . \mathrm{u} . / \mathrm{ml})$, which was replaced every day. Aseptic precautions were taken throughout surgery and when handling the foetal cannula after surgery.

The animals were allowed to recover from surgery for periods ranging from 7 to $11 \mathrm{~d}$ and the ewes were always eating all their food allocation before experiments began. In this period the ewes were accustomed to standing in a stanchion in a climate room. Experiments were carried out between 113 and $137 \mathrm{~d}$ of gestation. The day before an experiment a polyvinyl cannula, filled with heparinized saline, was placed in a maternal jugular vein using the Seldinger (1953) technique, and its tip advanced to the right side of the heart. On the day of an experiment a ewe was placed in a climate room, at approximately 10.00 hours, at a neutral $\left(15\right.$ or $25^{\circ}$, depending whether it was with fleece or clipped) or a cold $\left(-2-0^{\circ}\right.$ when clipped to a fleece length of approximately $5 \mathrm{~mm}$ ) environmental temperature. The heparinized saline was carefully withdrawn from maternal and foetal cannulas and replaced by saline. Samples $(5 \mathrm{ml})$ of maternal venous blood were withdrawn $0.5,1,1.5$ and $2 \mathrm{~h}$ after entry into the room and a similar volume of foetal arterial blood was withdrawn after the last maternal sample had been taken. Samples from three animals were withdrawn into syringes containing one drop of concentrated heparin solution, but samples from two animals were withdrawn into $0.5 \mathrm{ml}$ isotonic saline containing $6 \mathrm{mg}$ EDTA and $0.7 \mathrm{mg}$ Trasylol (Bayer Ltd, Haywards Heath). Blood was centrifuged and the plasma stored at $-18^{\circ}$. The sequence of experimental treatments was varied so that three ewes were exposed to the neutral temperature first and cold temperature second, and two ewes vice versa; the interval between experiments varied from 2 to $6 \mathrm{~d}$. All ewes delivered live lambs normally, near to expected term.

The concentration of glucose in plasma was measured using the enzyme glucose oxidase (EC 1.1.3.4; Werner et al. 1970), glycerol using the enzyme glycerol kinase (EC 2.7.1.30; Garland \& Randle, 1962) and non-esterified fatty acids by converting them to copper salts 
(Duncombe, 1964). Concentrations of insulin (Bassett \& Thorburn, 1971), growth hormone (Wallace \& Bassett, 1970) and corticosteroids (Bassett \& Hinks, 1969) were measured by radioimmunoassay. Pancreatic and total glucagon-like immunoreactivity in plasma were measured with a pancreatic-glucagon specific antibody (Unger 30K) and a non-specific antibody cross-reacting equally with pancreatic glucagon and gut glucagon (J. G. Manns GP 26) using the method of Bassett (1972). The difference between total glucagon-like immunoreactivity and pancreatic glucagon concentrations has been called 'gut-glucagon' concentration.

Chronic cold exposure. The twenty-six Scottish Blackface sheep were allocated randomly to two groups for the last 5-6 weeks of pregnancy: thirteen control ewes were housed in a climate room at $15^{\circ}$ (thermoneutral) and thirteen experimental ewes were clipped to maintain a depth of fleece between 5 and $8 \mathrm{~mm}$ and kept in pens, each holding three or four animals, in a climate room in which the air temperature was initially $6^{\circ}$ but gradually reduced to 1 or $2^{\circ}$ as term approached. Both groups of animals consumed the same food ration of ( $\mathrm{g} /$ animal per $\mathrm{d}$ ) 1000 hay, 1000 concentrated food plus turnip. Length of gestation and lamb birth weight were noted.

Statistics. Student's paired $t$ test was used to estimate the significance of changes in blood metabolite and hormone concentrations that occurred in animals that were exposed to both neutral and cold environments. The absolute concentrations of many hormones are not normally distributed but their logarithms often are (Bassett \& Thorburn, 1971) therefore concentrations of hormones were converted to logarithms for all statistical procedures. Results are expressed as antilogarithms of the means with their standard errors. The significances of differences of birth weight were tested by analysis of variance with terms fitted for thermal environment and litter size.

\section{RESULTS}

\section{Acute cold exposure}

Table 1 shows the mean concentrations of nutrients and hormones in maternal and foetal plasma during exposure of five pregnant ewes for $2 \mathrm{~h}$ to neutral and to cold environments, and the difference and standard error of the difference between these means. The cold environment increased the concentration of glucose in maternal plasma throughout the period between 0.5 and $2 \mathrm{~h}$ of exposure. At the end of $2 \mathrm{~h}$ in the cold, foetal plasma glucose concentration was also higher than control values in the neutral environment. Cold exposure also increased the concentrations of non-esterified fatty acids and glycerol in maternal plasma, both increases becoming greater with time in the cold environment, but foetal plasma concentrations of non-esterified fatty acids and glycerol were not affected.

The concentration of corticosteroids in maternal plasma was increased during cold exposure, the increase becoming greater with time in the cold environment, but the concentration of corticosteroids in foetal plasma was not affected. The concentration of insulin in foetal plasma was increased after $2 \mathrm{~h}$ of maternal cold exposure. There were no significant effects of maternal cold exposure on foetal plasma concentrations of pancreatic glucagon, gut glucagon or growth hormone.

\section{Chronic cold exposure}

The duration of gestation averaged $146.1 \mathrm{~d}$ in the control ewes, and in ewes that were exposed to cold during the last 5-6 weeks of pregnancy the average was $146.9 \mathrm{~d}$. Two of the thirteen ewes in the control environment had single lambs and the remainder had twins. Six of the thirteen cold-exposed ewes had single lambs and the remainder had twins. Table 2 shows the mean birth weights of single and twin lambs from ewes that were exposed to the two different environmental temperatures. Analysis of variance, of the individual 
Table 1. Mean concentrations of glucose, non-esterified fatty acids (NEFA), glycerol and corticosteroids in maternal and foetal plasma, and the concentrations of insulin, pancreatic glucagon, gut glucagon and growth hormone in foetal plasma of five pregnant sheep exposed to a neutral environmental temperature and to a cold $\left(-1 \pm 1^{\circ}\right.$ and clipped) temperature for $2 h$

\begin{tabular}{|c|c|c|c|c|c|}
\hline \multirow[b]{2}{*}{ Plasma constituent } & \multirow{2}{*}{$\begin{array}{l}\text { Period of } \\
\text { exposure } \\
\text { (h) }\end{array}$} & \multirow[b]{2}{*}{ Neutral } & \multirow[b]{2}{*}{ Cold } & \multicolumn{2}{|c|}{ Difference } \\
\hline & & & & Mean & SE \\
\hline \multirow[t]{4}{*}{ Maternal glucose (mmol/l) } & 0.5 & 3.78 & $4 \cdot 68$ & 0.90 & $0.292^{*}$ \\
\hline & 1 & 3.90 & $4 \cdot 78$ & 0.88 & $0 \cdot 193^{*}$ \\
\hline & 1.5 & $3 \cdot 70$ & $4 \cdot 60$ & 0.90 & $0.219^{*}$ \\
\hline & 2 & 3.68 & $4 \cdot 36$ & 0.68 & $0.097^{* *}$ \\
\hline Foetal glucose (mmol/1) & 2 & $1 \cdot 03$ & 1.44 & 0.41 & $0 \cdot 113^{*}$ \\
\hline \multirow{4}{*}{ Maternal NEFA (mmol/l) } & $0 \cdot 5$ & 0.38 & 0.51 & $0 \cdot 13$ & 0.118 \\
\hline & 1 & 0.35 & 0.46 & 0.11 & 0.103 \\
\hline & 1.5 & 0.35 & 0.62 & $0 \cdot 27$ & $0 \cdot 140$ \\
\hline & 2 & 0.35 & 0.69 & $0 \cdot 34$ & $0.117^{*}$ \\
\hline Foetal NEFA (mmol/l) & 2 & $0 \cdot 14$ & $0 \cdot 12$ & $0 \cdot 02$ & 0.013 \\
\hline \multirow[t]{4}{*}{ Maternal glycerol (mmol/1) } & 0.5 & 0.042 & 0.067 & 0.025 & $0 \cdot 0085^{*}$ \\
\hline & 1 & 0.039 & 0.081 & $0 \cdot 042$ & $0.0114^{*}$ \\
\hline & $1 \cdot 5$ & 0.049 & 0.092 & 0.043 & $0.0105^{*}$ \\
\hline & 2 & 0.046 & $0 \cdot 105$ & 0.059 & $0.0150^{*}$ \\
\hline Foetal glycerol (mmol/l) & 2 & 0.018 & 0.021 & 0.003 & 0.0029 \\
\hline \multirow[t]{4}{*}{ Maternal corticosteroids $(\mathrm{ng} / \mathrm{ml}$ ) } & 0.5 & $16 \cdot 4$ & $22 \cdot 3$ & 5.9 & $5 \cdot 0$ \\
\hline & 1 & $18 \cdot 6$ & $25 \cdot 7$ & $7 \cdot 1$ & $7 \cdot 5$ \\
\hline & $1 \cdot 5$ & $15 \cdot 7$ & $27 \cdot 5$ & 11.8 & $4 \cdot 0^{*}$ \\
\hline & 2 & $14 \cdot 0$ & $41 \cdot 2$ & $27 \cdot 2$ & $4 \cdot 8^{* *}$ \\
\hline Foetal: Corticosteroids $(\mathrm{ng} / \mathrm{ml})$ & 2 & $22 \cdot 0$ & $21 \cdot 1$ & 0.9 & 1.9 \\
\hline Insulin $(\mathrm{ng} / \mathrm{ml})$ & 2 & 0.50 & 0.77 & 0.27 & $0.09^{*}$ \\
\hline Pancreatic glucagon $(\mathrm{pg} / \mathrm{ml})$ & 2 & 107 & 128 & 21 & 12 \\
\hline Gut glucagon $(\mathrm{pg} / \mathrm{ml})$ & 2 & 220 & 249 & 29 & 46 \\
\hline Growth hormone $(\mathrm{ng} / \mathrm{ml})$ & 2 & $54 \cdot 4$ & $40 \cdot 6$ & $13 \cdot 8$ & 8.8 \\
\hline
\end{tabular}

${ }^{*} P<0.05, \quad{ }^{* *} P<0.01$

weights of singles and twins, showed that lambs from the cold-treated ewes were significantly heavier than those from the control ewes $(F 4.103, P<0.05)$ and that there was no significant difference in the way twins or singles responded to treatment. Total litter weight was also greater, by $0.65 \mathrm{~kg}$, in the cold-treated ewes $(F 4.69, P<0.05)$.

\section{DISCUSSION}

It is clear from the results of Armstrong et al. (1960) that the cold conditions employed in the present experiments would have increased the loss of energy from pregnant ewes to their environment. Food intake, and therefore gross energy intake, of the cold-exposed ewes was matched with that of control ewes, but less metabolizable energy may have been available to the experimental ewes because cold exposure hastens movement of food through the gut and reduces digestion (Westra \& Christopherson, 1976). Despite the adverse effect on energy balance, during the last 5-6 weeks of pregnancy, the birth weights of single and twin lambs from the cold-treated ewes were increased slightly. Gestation was slightly prolonged by exposure to cold, but this would have increased birth weight by less than $100 \mathrm{~g}$ (Mellor \& Murray, 1981 ; D. J. Mellor, personal communication). These results therefore confirm that exposing pregnant ewes to a cold environment can change the partition of nutrients between mother and foetus in favour of the foetus. 
Table 2. The birth weights of lambs from ewes that were exposed to thermoneutral and cold environments during the last 5-6 weeks of pregnancy

(Values are means with their standard errors)

\begin{tabular}{|c|c|c|}
\hline & \multicolumn{2}{|c|}{ Environment } \\
\hline & Thermoneutral & Chronic cold \\
\hline $\begin{array}{l}\text { No. of ewes } \\
\text { No. of lambs: }\end{array}$ & 13 & 13 \\
\hline Singles & 2 & 6 \\
\hline Twins & 22 & 14 \\
\hline Birth weight $(\mathrm{kg})$ : & & \\
\hline Singles & $\begin{array}{l}3 \cdot 3 \pm 0.60 \\
3 \cdot 1+0 \cdot 14\end{array}$ & $4 \cdot 2+0 \cdot 18$ \\
\hline Twins & $3.1 \pm 0.14$ & $3.4 \pm 0.12$ \\
\hline
\end{tabular}

Measurements of the concentrations of substrates and hormones in foetal plasma, during maternal cold exposure, suggest how a change in partition of nutrients may occur. Acute exposure to cold increased the concentrations of glucose, non-esterified fatty acids, glycerol and corticosteroids in maternal plasma, as in previous experiments (Halliday et al. 1969; Aulie et al. 1971; Panaretto \& Vickery, 1972). The high concentration of corticosteroids in maternal plasma did not produce a high concentration in foetal plasma, and previous experiments have shown only a small transfer of maternal cortisol to the foetus (Dixon et al. 1970). The concentrations of glucose in maternal and foetal plasma are, however, known to be positively correlated (Comline \& Silver, 1970) and cold exposure increased the concentrations of glucose in maternal and foetal plasma. Any transfer of non-esterified fatty acids from the ewe to its foetus is small (James et al. 1971; Elphick et al. 1979) and maternal cold exposure had no effect on the concentration of non-esterified fatty acids in foetal plasma. Cold exposure also did not affect the concentration of glycerol in foetal plasma although measurable quantities of glycerol cross the sheep's placenta (James et al. 1971).

Foetal lambs respond to infusion of exogenous glucose with an increased concentration of insulin in their plasma (Bassett \& Madill, 1974) and in the present experiments the increased foetal plasma glucose concentration brought about by maternal cold exposure was accompanied by an increased concentration of insulin in foetal plasma. Insulin may have an anabolic effect on the foetus, and it has been suggested that the foetal overgrowth associated with maternal diabetes is due to foetal hyperglycaemia and hyperinsulinaemia (Pedersen, 1975). No significant effects of cold exposure on the concentrations of pancreatic glucagon, gut glucagon or growth hormone in foetal plasma were observed.

To summarize, when sheep are exposed to a cold environment some substrates are mobilized into the circulation; glucose is among them because gluconeogenesis is stimulated (McKay et al. 1974). When pregnant sheep are exposed to cold, some of this additional circulating glucose may cross the placenta, increase glucose supply to the foetus and stimulate insulin secretion in the foetus. The partition of nutrients between mother and foetus may thus change in favour of the foetus.

The authors would like to thank $\mathrm{M}$. Bacon for assistance with foetal surgery, and Miss J. E. Forster for assistance with statistical analysis.

REFERENCES

Armstrong, D. G., Blaxter, K. L., Clapperton, J. L., Graham, N. McC. \& Wainman, F. W. (1960). J. agric. Sci., Camb. 55, 395.

Aulie, A., Astrup, H. N., Nedkvitne, J. J. \& Velle, W. (1971). Acta vet. scand. 12, 496. 
Austin. A. R. \& Young, N. E. (1977), Vet. Rec. 100, 527.

Bassett. J. M. (1972). Aust. J. biol. Sci. 25, 1277.

Bassett. J. M. \& Hinks, N. T. (1969), J. Endocr. 44. 387.

Bassett. J. M. \& Madill, D. (1974). J. Endocr. 62, 299.

Bassett. J. M. \& Thorburn, G. D. (1971). J. Endocr. 50, 59.

Bell. A. W.. Gardner, J. W., Manson, W. \& Thompson, G. E. (1975). Br. J. Nutr. 33, 207.

Bell. A. W. \& Thompson. G. E. (1979). Am. J. Physiol. 237, E309.

Comline, R. S. \& Silver, M. (1970). J. Physiol., Lond. 209, 567.

Comline. R. S. \& Silver, M. (1972). J. Physiol., Lond. 222, 233.

Dixon, R.. Hyman, A.. Gurpide, E., Dyrenfurth, I., Cohen, H., Bowe, E., Engel, T., Daniel, S., James, S. \& Vande Wiele. R. (1970). Steroids 16, 771.

Duncombe, W. G. (1964). Clinica chim. Acta 9, 122.

Elphick, M. C.. Hull, D. \& Broughton Pipkin, F. (1979). J. Dev. Physiol. 1, 31.

Garland. P. B. \& Randle. P. J. (1962). Nature, Lond. 196, 987.

Halliday, R.. Sykes, A. R., Slee, J., Field, A. C. \& Russel, A. J. F. (1969). Anim. Prod. 11, 479.

James. E., Meschia, G. \& Battaglia, F. C. (1971). Proc. Soc. exp. Biol. Med. 138, 823.

McKay, D. G., Young, B. A. \& Milligan, L. P. (1974). In Energy Metabolism of Farm Animals, pp. $39-42$.

Hohenheim: Universität Hohenheim Dokumentationsstelle.

Mellor. D, J. \& Murray, L. (1981), Res. vet. Sci. 30, 198.

Panaretto, B. A. \& Vickery, M. R. (1972). J. Endocr. 55, 519.

Pedersen, J. (1975). In Carbohydrate Metabolism in the Fetus and Newborn, pp. 247-273 [H. W. Sutherland \& J. M. Stowers, editors]. London: Churchill Livingston.

Robinson, J. J. (1977). Proc. Nutr. Soc. 36, 9.

Rutter, W., Laird, T. R. \& Broadbent, P. J. (1971). Anim. Prod. 13, 329.

Rutter, W., Laird, T. R. \& Broadbent, P. J. (1972). Anim. Prod. 14, 127.

Seldinger. S. I. (1953). Acta Radiol, Stockh. 39, 368.

Ternouth. J. H. \& Beattie, A. W. (1970). Anim. Prod. 12. 343.

Thompson, G. E., Bassett, J. M. \& Bell, A. W. (1978). Br. J. Nutr. 39, 219.

Wallace. A. L. C. \& Bassett, J. M. (1970). J. Endocr. 47, 21.

Webster, M. E. D. \& Lynch, J. J. (1966). Proc. Aust. Soc. Anim. Prod. 6, 234.

Werner, W., Rey, H.-G. \& Wielinger, H. (1970). Z. analyt. Chem. 252, 224.

Westra. R. \& Christopherson, R. J. (1976). Can. J. anim. Sci. 56, 699.

Wodzicka-Tomaszewska, M. (1963). N.Z. Jl agric. Res. 6, 440. 